\title{
Adsorption properties of sugarcane bagasse and corn cob for the sulfamethoxazole removal in a fixed-bed column
}

\author{
Diego Juela, Mayra Vera, Christian Cruzat, Ximena Alvarez and Eulalia Vanegas* (B)
}

\begin{abstract}
Natural adsorbents are a good alternative to remove antibiotic residues from wastewater. In this study, the adsorption capacity of sulfamethoxazole (SMX) onto sugarcane bagasse (SB) and corn cob (CC) in a continuous fixed-bed was compared. Brunauer Emmett Teller, Fourier transform infrared (FTIR), Boehm titration, and point of zero charge $\left(\mathrm{pH}_{\mathrm{pzc}}\right)$ were used to characterize both adsorbents. The adsorption capacity $\left(\mathrm{q}_{\mathrm{e}}\right)$ and the removal percentage of SMX (\% R) were investigated at different different flow rates $\left(2,5\right.$, and $\left.7 \mathrm{~mL} \mathrm{~min}^{-1}\right)$ and adsorbent masses ( 4 and $6.4 \mathrm{~g}$ ), and a constant initial concentration of $5 \mathrm{mg} \mathrm{L}^{-1}$. The results of the characterization showed that SB has a morphology with more dispersed particles and a specific surface higher than CC $\left(2.6>1.2 \mathrm{~m}^{2} \mathrm{~g}^{-1}\right)$. Boehm titration indicates that both the surface of SB and CC have a greater amount of acid groups, which is in agreement with FTIR and $\mathrm{pH}_{\mathrm{pzc}}$ results. The continuous fixed-bed experiments showed that $\% \mathrm{R}$ and $\mathrm{q}_{\mathrm{e}}$ of $\mathrm{SMX}$ are higher with SB in all the tests. The highest $\mathrm{q}_{\mathrm{e}}$ and maximum \% $\mathrm{R}$ was $0.24 \mathrm{mg} \mathrm{g}^{-1}$ and $74 \%$ with $\mathrm{SB}$, and $0.15 \mathrm{mg}$ $\mathrm{g}^{-1}$ and $65 \%$ using CC. In most cases, the $\mathrm{q}_{\mathrm{e}}$ of both adsorbents decreased with the increase of flow rate and bed height. An analysis suggests that hydrogen bonds could be the main factor favoring the SMX adsorption with SB. Finally, the intraparticle diffusion was the rate-controlling step, predominating the pore-volume diffusion resistance.
\end{abstract}

Keywords: Antibiotics removal, Wastewaters treatment, Biosorption, Natural adsorbents, Adsorption capacity

\section{Introduction}

Antibiotics are widely used in humans and animals to fight diseases caused by bacteria. In animals, they have also been used to a great extent to promote their growth and for the prophylaxis of diseases. After administration, they are partially metabolized, and a significant portion of the antibiotic can be excreted in the urine or feces as the parent compound or in conjugated forms. In fact, it has been estimated that between 70 and $90 \%$ of antibiotics administered in animals are excreted through urine and feces [1]. As a result, these residues of antibiotics and their metabolites are released into the environment.

\footnotetext{
* Correspondence: eulalia.vanegas@ucuenca.edu.ec

Department of Applied Chemistry and Production Systems, University of Cuenca, 010203 Cuenca, Ecuador
}

Residual antibiotics for human and animal use can enter the environment through several pathways, including domestic and hospital wastewaters discharge, leaching, and runoff from land to which animal wastes with antibiotics have been applied [2].

Sulfamethoxazole (SMX) is a bacteriostatic antibiotic, and it is commonly used to treat urinary tract infections, sinusitis, and toxoplasmosis. After being ingested, SMX and its main metabolite, $\mathrm{N}_{4}$-acetyl-sulfamethoxazole (Ac-SMX), are excreted in the urine. In human metabolism, SMX and Ac-SMX are excreted in approximately $15-25$ and $50 \%$ of the administered dose, respectively [3]. However, in animal metabolism, approximately $70 \%$ is excreted as the parent compound, and $28 \%$ as AcSMX [4]. SMX and Ac-SMX have been found in

(c) The Author(s). 2021 Open Access This article is licensed under a Creative Commons Attribution 4.0 International License, which permits use, sharing, adaptation, distribution and reproduction in any medium or format, as long as you give appropriate credit to the original author(s) and the source, provide a link to the Creative Commons licence, and indicate if changes were made. The images or other third party material in this article are included in the article's Creative Commons licence, unless indicated otherwise in a credit line to the material. If material is not included in the article's Creative Commons licence and your intended use is not permitted by statutory regulation or exceeds the permitted use, you will need to obtain permission directly from the copyright holder. To view a copy of this licence, visit http://creativecommons.org/licenses/by/4.0/. 
domestic and hospital wastewaters. Normally, their concentration varies in the range of $\mathrm{ng} \mathrm{L}^{-1}$ and $\mu \mathrm{g} \mathrm{L}^{-1}$. In Canada, SMX was the most concentrated antibiotic in effluents of a wastewater treatment plant (WTP) with $3.28 \mu \mathrm{g} \mathrm{L}^{-1}$ [5]. Similarly, in China SMX and Ac-SMX were detected in WTP influents in the concentration range between $13.5-152$ and $83-299 \mathrm{ng} \mathrm{L}^{-1}$, respectively, while in the effluents their concentrations were reduced to 11.4-145 and 89-208 $\mathrm{ng} \mathrm{L}^{-1}$, respectively [6].

Multiple studies have shown that the conventional WTPs are ineffective in completely removing antibiotic residues, with a removal percentage for SMX only between 20 to $90 \%$ [7]; and in some cases, even a negative removal efficiency has been reported [8]. Due to the ineffectiveness of WTPs to eliminate SMX, this antibiotic has currently been found in surface waters, groundwater, and even in drinking water [9]. For instance, in freshwaters from Africa and Germania SMX was found in concentrations of up to $53.8 \mathrm{\mu g} \mathrm{L}^{-1}$ and $100 \mathrm{ng} \mathrm{L}^{-1}$, respectively $[10,11]$. In North Carolina, SMX was found at values lower than $10 \mathrm{ng} \mathrm{L}^{-1}$ [12]. Similarly in Ecuador, SMX reached drinking water at a concentration lower than $20 \mathrm{n} \mathrm{L}^{-1}$ [13]. Although the levels of SMX found in surface and drinking water are not high enough to affect human and animal health, due to the frequent, extensive, and uninterrupted use of these types of drugs, these very low concentrations could pose a threat to the development of antibiotic resistant bacteria.

Adsorption is an effective and appropriate technology to remove antibiotic residues present in wastewaters at very low concentrations. Many adsorbents have been studied to remove SMX such as granular activated carbon, lignite activated coke, microporous organic polymers, graphene nanocomposite, metal-organic frameworks, biochar, and other carbon-based materials with high adsorption capacity $\left(>100 \mathrm{mg} \mathrm{g}^{-1}\right)$ [14, 15], and they could be ideal for pilot and industrial applications. However, the methods of obtaining these adsorbents are expensive, so their large-scale application is economically unfeasible. For this reason, scientists have intensified the development and search for low-cost adsorbents. Materials like agricultural waste, industrial byproducts, and natural materials with little processing can be used as adsorbents for the removal of antibiotics. All these materials have good properties and have the advantage in that their production cost is very low. Some of the raw materials that have been used for SMX removal in batch are spent mushroom substrate, corn cob (CC), peanut shell, walnut shell, agricultural soil, and sugarcane bagasse $(\mathrm{SB})[16,17]$.

$\mathrm{CC}$ and SB are two lignocellulosic residues with high potential to be used as adsorbents in Ecuador due to their large production and availability. In Ecuador, for every $\mathrm{kg}$ of corn harvested, $0.186 \mathrm{~kg}$ of $\mathrm{CC}$ are produced
[18]. Similarly, $1 \mathrm{~kg}$ of SB is obtained for every $3.5 \mathrm{~kg}$ of sugar cane processed [19]. In the literature consulted there are few studies that use SB and CC in their natural state for the removal of pharmaceutical compounds. SB and $\mathrm{CC}$ have shown good adsorption properties for the removal of ciprofloxacin, acetaminophen, and tetracycline $[20,21]$, with an adsorption capacity greater than 5 $\mathrm{mg} \mathrm{g}^{-1}$ in batch studies. However, their efficacy in removing SMX and other antibiotics in a fixed-bed column has not yet been studied.

In this study, the adsorption properties of two lowcost adsorbents, SB and CC, for removing SMX from synthetic solutions were investigated. Knowing their potential as adsorbents to remove antibiotics is our prime aim. With this information, we will know which of these adsorbents has a better practical utility and could be used for further studies to improve even more its adsorption properties with methods such as surface modification, production of composites, among other approaches. The adsorption studies were carried out in a lab-scale fixed-bed column, and the effect of the bed height and flow rate was investigated. Besides, the transport parameters were estimated to elucidate the ratelimiting step in the SMX adsorption.

\section{Materials and methods \\ Reagents}

SMX with a purity of $99 \%$ supplied by Sigma-Aldrich was used in this study. Methanol of analytical grade Merck with a purity of $99 \%$ was used to dissolve SMX. The SMX solutions were prepared with distilled water and with $1 \% \mathrm{v} / \mathrm{v}$ methanol. All synthetic solutions had a concentration of $5 \mathrm{mg} \mathrm{L}^{-1}$ of SMX. The $\mathrm{pH}$ of the solution was adjusted to 6 with addition of $0.1 \mathrm{~N} \mathrm{HCl} \mathrm{solu-}$ tion. The initial and residual concentrations of SMX were determined by the Visible Genesys 10S UV spectrophotometry technique from Thermo SCIENTIFIC, at a wavelength of $261 \mathrm{~nm}$. The physicochemical properties of SMX are detailed in Table 1.

\section{Adsorbents' preparation and characterization}

Raw SB and CC were obtained from a sugar mill and a local farm, in Azuay, Ecuador. Before their use in adsorption tests, SB and CC were washed repeatedly with distilled water in order to remove impurities and residual sugars. Then, these were dried in an oven at $60^{\circ} \mathrm{C}$ for $8 \mathrm{~h}$. Finally, the size of the fibers was reduced using a hammer mill and subsequent sieving. The fraction with a particle diameter between 0.84 and $0.42 \mathrm{~mm}$ was characterized and eventually used in the adsorption tests.

As physical properties, the specific surface area was estimated using Brunauer Emmett Teller method by nitrogen physisorption using an ASAP 2020 Micromeritic instrument; the bulk density, particle density, and the 
Table 1 Physicochemical properties of sulfamethoxazole

\begin{tabular}{ll}
\hline Parameter & Description \\
\hline Molecular formula & $\mathrm{C}_{10} \mathrm{H}_{11} \mathrm{~N}_{3} \mathrm{O}_{3} \mathrm{~S}$
\end{tabular}

Molecular structure

Molecular weight $\left(\mathrm{g} \mathrm{mol}^{-1}\right)$

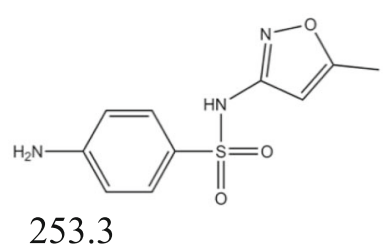

Molar volume at its normal boiling

173.1 point $\left(\mathrm{cm}^{3} \mathrm{~mol}^{-1}\right)$

Solvent association parameter of water

Acid dissociation constant

$\mathrm{pK}_{\mathrm{a} 1}=1.7 ; \mathrm{pK}_{\mathrm{a} 2}=5.7$

Octanol/water partition coefficient

0.86

Henry's law coefficient $\left(\mathrm{atm} \mathrm{m}^{3} \mathrm{~mol}^{-1}\right)$

$6.42 \mathrm{e}^{-13}$

Water solubility at $293 \mathrm{~K}\left(\mathrm{mg} \mathrm{L}^{-1}\right)$

600

\author{
$\mathrm{pH}$ dependence of SMX speciation
}

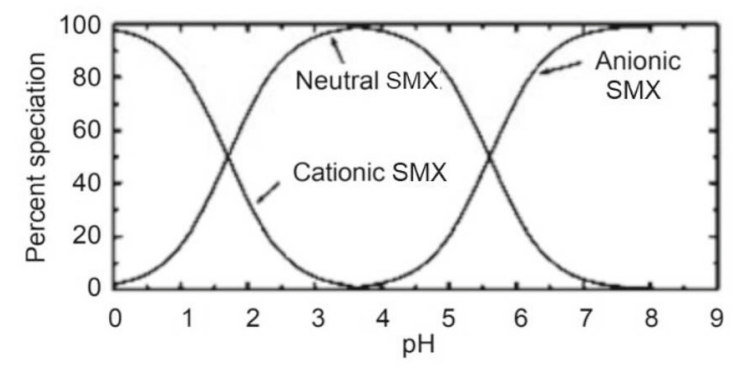

bed porosity were also estimated with the methodology described in our previous study [22]. Regarding chemical properties, the amount of surface acidic and basic groups of both adsorbents were quantified by the acidbase titration method. The point of zero charge $\left(\mathrm{pH}_{\mathrm{PZC}}\right)$ was determined by the potentiometric curves, and the functional groups of SB and CC were identified with FTIR spectroscopy. The spectra were obtained using a HATR attenuated total reflectance accessory, with a ZnSe crystal and a resolution of $4 \mathrm{~cm}^{-1}$ and 100 scans in the range of 4000 and $1300 \mathrm{~cm}^{-1}$.

\section{Continuous fixed-bed experiments}

A glass column $35 \mathrm{~cm}$ in height and $2.2 \mathrm{~cm}$ in internal diameter was used for the adsorption tests. For the experimental setup of the column, the adsorbent previously weighed was introduced into the inside the column, and $1 \mathrm{~cm}$ of gravel of $2 \mathrm{~mm}$ diameter was placed at the bottom and the top of the fixed-bed to prevent the adsorbent from being entrained by the solution and to avoid the floating of the bed and provide a better distribution of the solution. The SMX solution was pumped into the bed by a peristaltic pump with downward flow and the samples were collected in the outlet of the column until the adsorbent was saturated.

Six studies were carried out with each adsorbent. The effect of flow rate $Q$ (at 2, 5 , and $7 \mathrm{~mL} \mathrm{~min}^{-1}$ ) and bed height $H$ (two heights corresponding to an adsorbent mass of 4 and $6.4 \mathrm{~g}$ ) on the breakthrough curve was studied as can been seen in Table 2. To compare the adsorption properties of the adsorbents, the same mass was used for each adsorbent $(\mathrm{m})$ in each test. 
Table 2 Experimental conditions in fixed-bed column studies

\begin{tabular}{|c|c|c|c|c|c|c|}
\hline \multirow{2}{*}{$\begin{array}{l}\text { Test } \\
\text { number }\end{array}$} & \multicolumn{3}{|l|}{ SMX-SB } & \multicolumn{3}{|l|}{ SMX-CC } \\
\hline & $\begin{array}{l}\mathrm{Q} \\
\left(\mathrm{mL} \min ^{-1}\right)\end{array}$ & $\mathrm{m}(\mathrm{g})$ & $\mathrm{H}(\mathrm{cm})$ & $\begin{array}{l}\mathrm{Q} \\
\left(\mathrm{mL} \min ^{-1}\right)\end{array}$ & m (g) & $\mathrm{H}(\mathrm{cm})$ \\
\hline 1 & 2 & 4 & 15 & 2 & 4 & 7 \\
\hline 2 & 5 & 4 & 15 & 5 & 4 & 7 \\
\hline 3 & 7 & 4 & 15 & 7 & 4 & 7 \\
\hline 4 & 2 & 6.4 & 25 & 2 & 6.4 & 11 \\
\hline 5 & 5 & 6.4 & 25 & 5 & 6.4 & 11 \\
\hline 6 & 7 & 6.4 & 25 & 7 & 6.4 & 11 \\
\hline
\end{tabular}

\section{Column performance analysis}

The performance column in each test was investigated with eight parameters that describe the operation of the fixed-bed column. The breakthrough time $\left(t_{b}\right)$ and saturation time $\left(t_{\mathrm{s}}\right)$ were estimated when the SMX concentration at the column outlet reaches $5 \%\left(C / C_{i}=0.05\right)$ and $75 \%\left(C / C_{i}=0.75\right)$ of the initial concentration, respectively. The volume of the SMX solution treated until the saturation time was estimated using Eq. (1).

$$
V=Q t_{s}
$$

The total amount of SMX removed $q_{\text {total }}(\mathrm{mg})$ is represented by the area under the breakthrough curve, and it was obtained by Eq. (2). The total amount of SMX passing through the adsorbent bed until saturation time $m_{t o-}$ tal (mg) was calculated using Eq. (3). When the adsorption column reaches equilibrium, the adsorption capacity $q_{e}\left(\mathrm{mg} \mathrm{g}^{-1}\right)$ can be determined by Eq. (4).

$$
\begin{aligned}
& q_{\text {total }}=\frac{Q}{1000} \int_{t=0}^{t=t s} C_{R} d t \\
& m_{\text {total }}=\frac{C_{i} Q t_{s}}{1000} \\
& q_{e}=\frac{q_{\text {total }}}{m}
\end{aligned}
$$

where $C_{R}$ is the concentration of SMX adsorbed (mg $\mathrm{L}^{-1}$ ), and $C_{i}$ is the initial concentration of SMX (mg $\mathrm{L}^{-1}$ ). Additionally, the total percentage of antibiotic removed $\% R$ was obtained from Eq. (5). Finally, the length of the unused bed LUB $(\mathrm{cm})$ was calculated using Eq. (6).

$$
\begin{aligned}
& \% R=\frac{q_{\text {total }}}{m_{\text {total }}} * 100 \\
& L U B=H\left(\frac{t_{s}-t_{b}}{t_{s}}\right)
\end{aligned}
$$

\section{Transport parameters}

To better understand which mechanism is the ratelimiting step in the SMX adsorption, the following transport parameters were estimated: film or external diffusion coefficient $k_{f}$, surface diffusion coefficient $D_{s}$, and pore volume diffusion coefficient $D_{p}$. The empirical correlations used are shown in Eqs. (7), (8), and (9) [21, 23].

$$
\begin{aligned}
& \frac{k_{f} d_{p}}{D_{m}}=2+1.58\left(\frac{d_{p} v \rho}{\mu}\right)^{0.4}\left(\frac{\mu}{\rho D_{m}}\right)^{1 / 3} \\
& \frac{15 D_{s}}{r_{p}^{2}}=0.00129\left(\frac{D_{m} C_{i}}{r_{p}^{2} q_{e}}\right)^{1 / 2} \\
& D_{p}=\frac{\varepsilon_{p} D_{m}}{\tau}
\end{aligned}
$$

where $D_{m}$ is the molecular diffusivity of SMX $\left(\mathrm{m}^{2} \mathrm{~s}^{-1}\right)$, $d_{p}$ is the particle diameter of the adsorbent $(\mathrm{m}), \mathrm{v}$ is the superficial velocity of the SMX solution $\left(\mathrm{m} \mathrm{s}^{-1}\right), \rho(\mathrm{kg}$ $\left.\mathrm{m}^{-3}\right)$ and $\mu\left(\mathrm{kg} \mathrm{m}^{-1} \mathrm{~s}^{-1}\right)$ are the density and the dynamic viscosity of the SMX solution, $r_{p}(\mathrm{~m})$ and $\varepsilon_{p}$ are the radius and porosity of the adsorbent particle (Table 3), and $\tau$ is the tortuosity factor of the adsorbent. $D_{m}$ and $\tau$ were estimated using Eqs. (10) and (11) [24].

$$
\begin{aligned}
& D_{m}=7.4 \times 10^{-8} \frac{(\alpha M)^{0.5} T}{\mu V_{m}^{0.6}} \\
& \tau=\frac{\left(2-\varepsilon_{p}\right)^{2}}{\varepsilon_{p}}
\end{aligned}
$$

where $\alpha$ is a solvent association parameter, $M\left(\mathrm{~g} \mathrm{~mol}^{-1}\right)$ is the molecular weight of the solvent, and $V_{m}\left(\mathrm{~cm}^{3}\right.$ $\mathrm{mol}^{-1}$ ) is the molar volume of SMX at its normal boiling point (see Table 1). Since the intraparticle diffusion involves both surface and pore diffusion, both mechanisms can be represented by an effective intraparticle diffusion coefficient $\left(D_{e}\right)$, Eq. (12) [23].

$$
D_{e}=\frac{D_{s}+D_{p}}{f^{\prime}(C) \rho_{b}}
$$

where $\rho_{b}$ is the bed porosity $\left(\mathrm{kg} \mathrm{m}^{-3}\right)$, and $f(C)$ is an average value of $d q / d C$ from an isotherm. The $f(C)$ was $0.029 \mathrm{~L} \mathrm{~g}^{-1}$ according our previous studies.

Table 3 Physical properties of SB and CC

\begin{tabular}{lll}
\hline Physical property & SB & CC \\
\hline Particle density $\left(\mathrm{g} \mathrm{L}^{-1}\right)$ & 188 & 637 \\
Bulk density $\left(\mathrm{g} \mathrm{L}^{-1}\right)$ & 70 & 158 \\
Bed void fraction & 0.63 & 0.75 \\
Average particle diameter $(\mathrm{m})$ & $5.9 \times 10^{-4}$ & $5.9 \times 10^{-4}$ \\
Adsorbent porosity & 0.21 & 0.59 \\
Specific surface area $\left(\mathrm{m}^{2} \mathrm{~g}^{-1}\right)$ & 2.6 & 1.2 \\
\hline
\end{tabular}




\section{Results and discussion}

\section{Characterization of adsorbents}

\section{Physical properties}

The obtained physical properties of SB and CC are shown in Table 3. The particle and bulk density of $\mathrm{CC}$ is greater than that of $\mathrm{SB}$, hence the bed height with $\mathrm{CC}$ is higher than with $\mathrm{SB}$ with the same amount of biosorbent (as can be seen in Table 2). Similarly, the bed porosity with $\mathrm{CC}$ was higher than with $\mathrm{SB}$, which means there is more space between the particles for the ACT solution to come into contact with CC. On the contrary, the value of the specific surface area of SB is twice the value of $\mathrm{CC}$ with the same particle size.

\section{Chemical properties}

Figures $1 \mathrm{a}$ and $\mathrm{b}$ show the determination of the point of zero charge, and was 6.1 and 5.5 for SB and $\mathrm{CC}$, respectively; which means that at this $\mathrm{pH}$ value, the total net charge on the surface of $\mathrm{SB}$ and $\mathrm{CC}$ is zero. Penafiel et al. [17] reported a pHpzc value of 5.9 for SB from Ecuador; this indicates that the pHpzc for this biosorbent is around 6, which means that $\mathrm{SB}$ has almost null surface charge at $\mathrm{pH}$ of SMX solutions. The $\mathrm{pH}_{\mathrm{pzc}}$ values also mean that both $\mathrm{SB}$ and $\mathrm{CC}$ have a slightly acid character. These results are in accordance with those reported by Vera et al. [22].

Figures $1 \mathrm{c}$ and $\mathrm{d}$ show the Boehm titration curves for SB and CC, respectively, and Table 4 shows the value
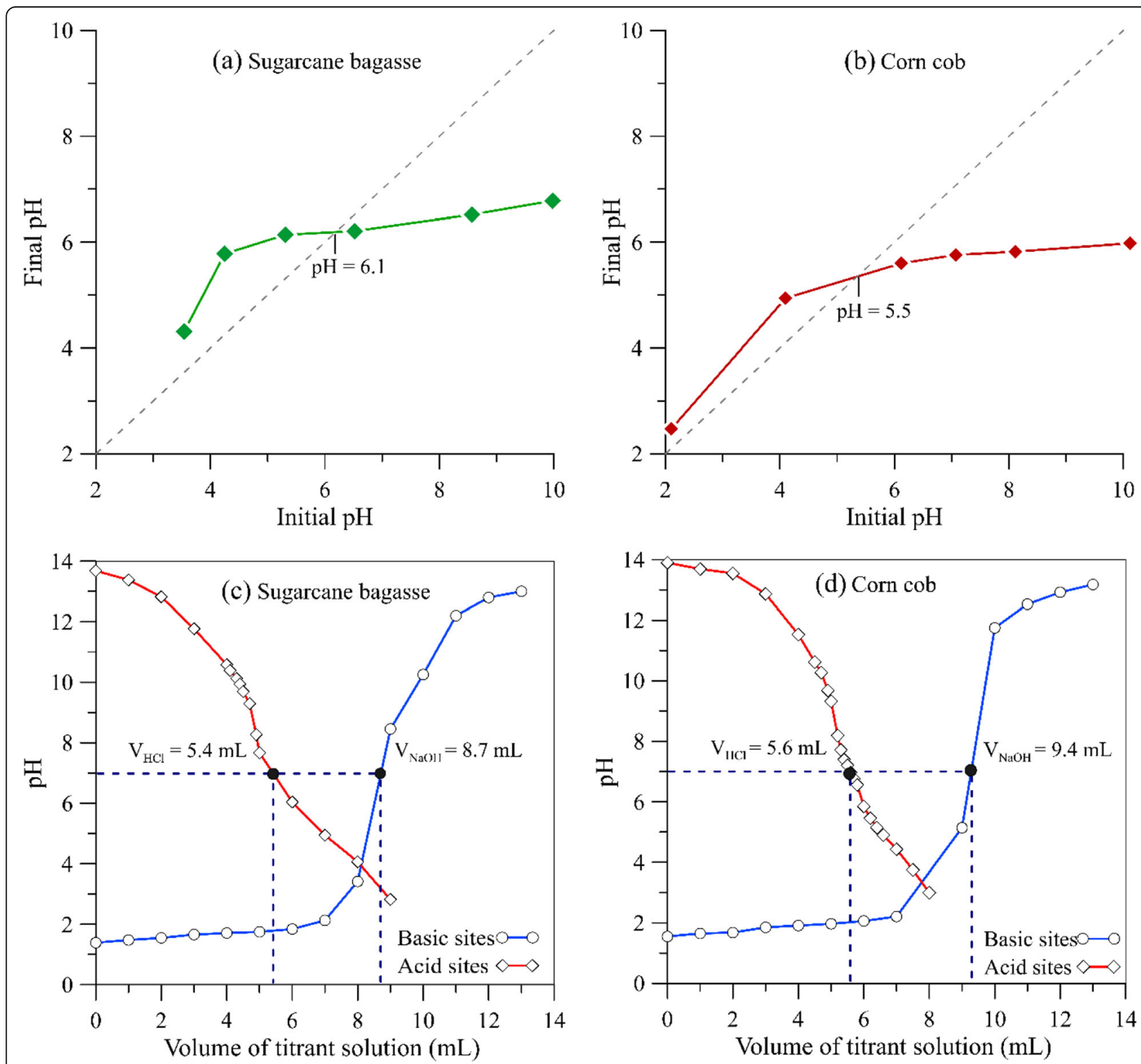

Fig. 1 pH $\mathrm{PZC}_{\mathrm{PC}}$ of SB (a) and CC (b), and titration curves for the acidic and basic sites of SB (c) and CC (d) 
Table 4 Total acid and basic groups of SB and CC

\begin{tabular}{llll}
\hline Adsorbent & Groups & Value $\left(\mathbf{m e q ~}^{\mathbf{- 1}}\right)$ & \% Groups \\
\hline SB & Total basic groups & 0.45 & 16 \\
& Total acid groups & 2.35 & 84 \\
CC & Total basic groups & 0.3 & 12 \\
& Total acid groups & 2.2 & 88 \\
\hline
\end{tabular}

and percentage of acid and basic groups. The results indicate that both SB and CC have a greater amount of acid functional groups rather than basic groups. These results are in agreement with those obtained for $\mathrm{pH}_{\mathrm{PZC}}$. The acid character of the surface of $\mathrm{SB}$ and $\mathrm{CC}$ shows that the carboxyl $(-\mathrm{COOH})$, lactone $(-\mathrm{OOR})$, and phenolic hydroxy $(-\mathrm{OH})$ groups are predominantly present on their surface [25]. Furthermore, a greater quantity of acidic sites translates into a greater presence of oxygenated functional groups, and this has been shown to

\section{(a)}

(b)
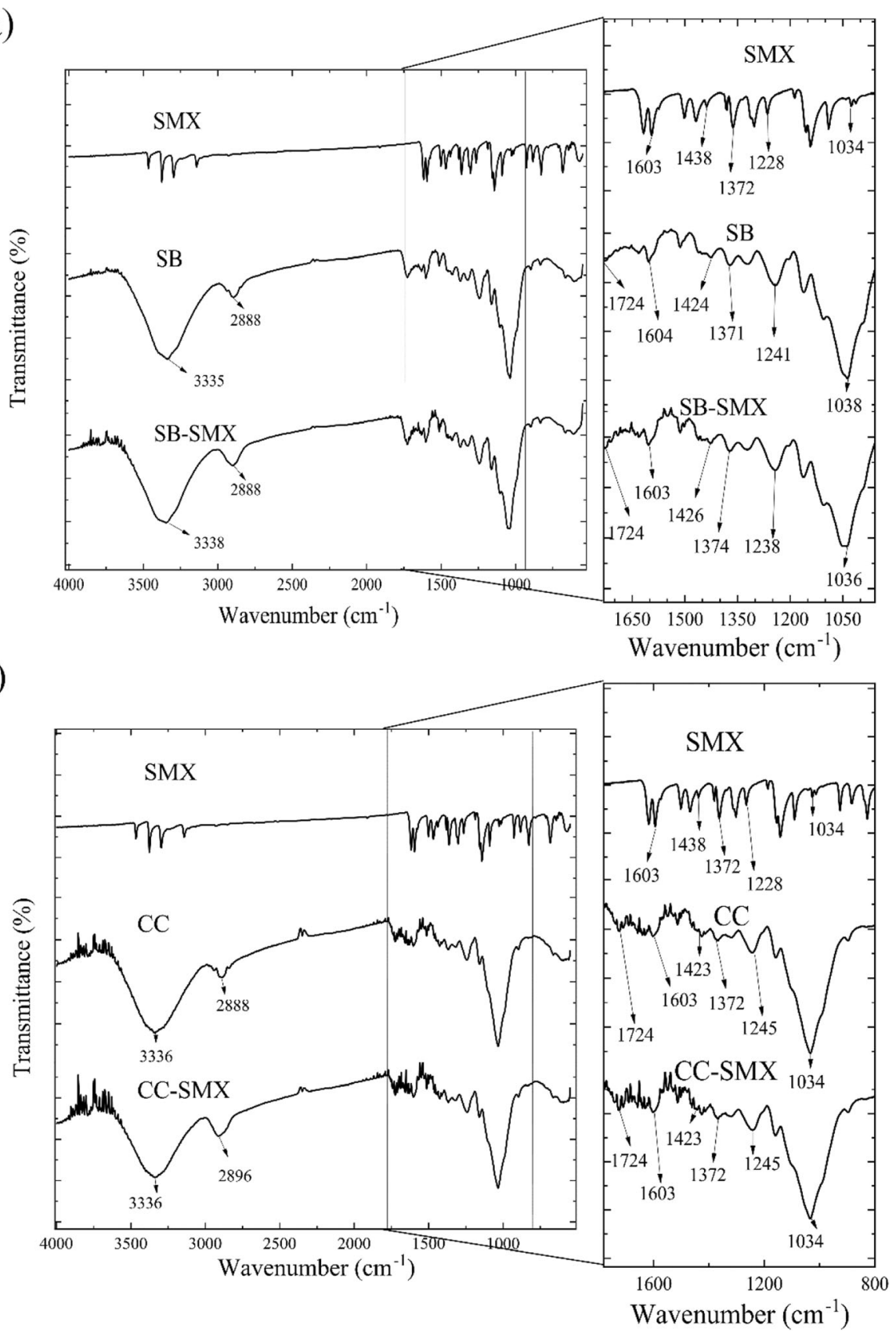

Fig. 2 FTIR spectrum of SB and SB-SMX (a), CC and CC-SMX (b) 
increase the adsorption capacity in activated carbons and chemically modified natural adsorbents [26]. For this reason, $\mathrm{SB}$ and $\mathrm{CC}$ could be potential adsorbents for SMX removal.

The FTIR analysis supported the Boehm titration results. Figure $2 \mathrm{a}$ and $\mathrm{b}$ show the infrared spectra of SMX, SB, CC, SB-SMX, and CC-SMX. An intense peak at $3336 \mathrm{~cm}^{-1}$ shows $\mathrm{O}-\mathrm{H}$ stretching of phenolic hydroxyl or carboxyl groups of SB and CC. The peak at 1724 $\mathrm{cm}^{-1}$ corresponds to $\mathrm{C}=\mathrm{O}$ stretching of carboxyl and lactone groups [27]. Also, the peak at around 1371$1374 \mathrm{~cm}^{-1}$ is assigned to C-O groups of carboxylic acid, alcoholic, and phenolic groups. Other major functional groups present are $\mathrm{C}-\mathrm{H}$ of aliphatic groups around $2888-2896 \mathrm{~cm}^{-1}$; C-O of ester and ether groups at $1034-1038 \mathrm{~cm}^{-1}$; stretching vibration of $\mathrm{C}=\mathrm{C}$ of aromatic rings at $1603 \mathrm{~cm}^{-1}$, and $\mathrm{C}-\mathrm{O}-\mathrm{C}$ and $\mathrm{C}-\mathrm{O}$ at $1238-$ $1245 \mathrm{~cm}^{-1}$ attributed to the bending of $\mathrm{CH}_{3}$ groups of cellulose and hemicellulose of SB and CC. After adsorption, some peaks are observed around $1400-1620 \mathrm{~cm}^{-1}$ attributed to $-\mathrm{N}-\mathrm{H}$ groups corresponding to SMX [28]. Additionally, for the spectra of $\mathrm{CC}$, the intensity of the absorption peaks at 3336 and $2888 \mathrm{~cm}^{-1}$ changed slightly to compare to CC-SMX spectra. Similarly, this happened for the spectra of SB and SB-SMX at the same peaks with a change more significant. This indicates that the SMX adsorption on SB and CC occurs mainly on O$\mathrm{H}, \mathrm{C}-\mathrm{H}$, and $\mathrm{C}-\mathrm{O}$ bonds, where hydrogen bonds are the most important interactions [29].

\section{Continuous fixed-bed experiments Effect of flow rate}

The effect of flow rate on the breakthrough curve was studied at 2, 5, and $7 \mathrm{~mL} \mathrm{~min}^{-1}$, at bed heights at 15 and $25 \mathrm{~cm}$, and at an initial concentration of $5 \mathrm{mg} \mathrm{L}^{-1}$. The results obtained with SB and CC are observed in Fig. 3.
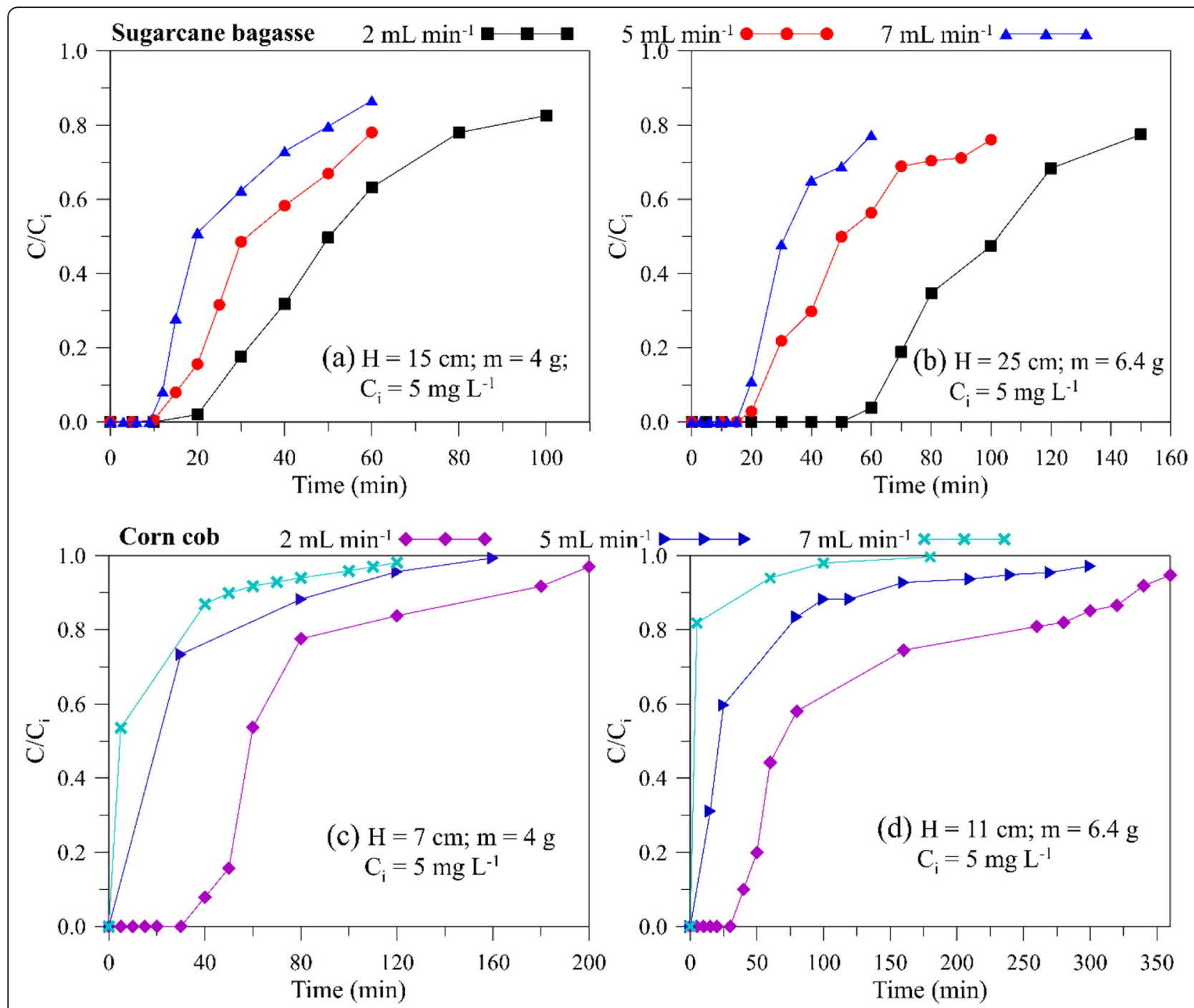

Fig. 3 Influence of flow rate on the breakthrough curve of the SMX adsorption with an initial concentration of $5 \mathrm{mg} \mathrm{L}^{-1}$ 
As evidenced in Fig. 3a and b, the breakthrough and saturation times increase as the flow rate decreases, this happens at 15 and $25 \mathrm{~cm}$. Thus, the breakthrough and saturation times are greater at lower flow rates (Table 5), which translates into more antibiotic adsorbed. While high flow rates tend to drive turbulence within the interstitial spaces of the bed, and this turbulence increases the possibility of axial dispersion effects occurring, limiting the diffusion of SMX into the pores of SB; this turbulence may be a cause for lower breakthrough and saturation times. Furthermore, the lower the flow rate, the longer the residence time of the SMX in the column, which means that there is a greater opportunity for SMX to reach the macropores of the adsorbent at low flow rates. This may be the main reason why $q_{t o-}$ tal decreases as the flow rate increases, as shown in Table 5. Furthermore, if the residence time of the SMX in the bed column is not long enough, the adsorption equilibrium is not reached within the column, since the solution with SMX leaves the column before it occurs [30].

Figure $3 \mathrm{c}$ and $\mathrm{d}$ show the influence of flow rate when corn cob is used. As with the SB, the adsorbent bed reaches saturation faster at high flow rates. In fact, when working at $7 \mathrm{~mL} \mathrm{~min}^{-1}$ and $7 \mathrm{~cm}$, the SMX concentration at the outlet of the column reaches half of the inlet concentration $\left(C / C_{i}=0.5\right)$ only $5 \mathrm{~min}$ after starting the operation. In the same way, it occurs at $7 \mathrm{~mL} \mathrm{~min}^{-1}$ and $11 \mathrm{~cm}$ of bed height. This shows the low affinity of SMX for CC when operating at high flow rates. A singularity that can be noticed is that the curves have a particular shape since in the initial region the curve is almost a straight line, then they present high slopes in the transitory region, and then decrease as they progress towards full saturation. Furthermore, the breakthrough curves do not present the sigmoidal tendency, which is generally observed in ideal adsorbate-adsorbent systems, with a favorable adsorbate removal; however, this tendency was not observed neither in the SMX-CC nor in SMX-SB. The high slopes in the curves reveal that the mass transfer is not controlled by diffusion, giving rise to the possibility of an instantaneous equilibrium between the liquid phase and the phase adsorbed.

\section{Effect of bed height}

Figure $4 \mathrm{a}$ shows the influence of the bed height for SB; the breakthrough curves were obtained at 15 and $25 \mathrm{~cm}$, and with a flow rate of $2 \mathrm{~mL} \mathrm{~min}^{-1}$. An increase in $H$ significantly prolongs the breakthrough and saturation time. For example, $t_{s}$ increases from 75.96 to $141.82 \mathrm{~min}$ when changing from 15 to $25 \mathrm{~cm}$ (Table 5). The increase in $H$ causes a greater quantity of adsorbent material, which means a greater surface area and therefore a greater quantity of active sites. Furthermore, with a higher bed height, the time it takes for the antibiotic solution to travel through the column is longer, which increases the contact time between the SMX and the active sites of the adsorbent.

The effect produced by the variation of $H$ in breakthrough curves is less significant with CC (Fig. 4b). Contrary to what happened with $\mathrm{SB}$, the breakthrough times practically coincide at both heights, for all the flow rates (Table 6). In effect, the curves overlap in the initial region, but as time passes, they begin to differ; hence the saturation times are different. The increase in $H$ from 7 to $11 \mathrm{~cm}$ results in a doubling $t_{s}$; for instance, it varied from $77.9 \mathrm{~min}$ to $168.2 \mathrm{~min}$ with a flow rate of $2 \mathrm{~mL}$ $\mathrm{min}^{-1}$ (Table 6). This effect may be due to the behavior of the fluid inside the column. At low bed heights, the effects of axial dispersion can be considerable and predominant in mass transfer phenomena, which leads to a difficult and slow diffusion of the SMX from the liquid to the solid phase. But at higher bed heights, the axial dispersion becomes negligible.

\section{Performance parameters of the adsorption column}

Table 5 shows the fixed-bed parameters when the column is packed with SB. The parameters $V$ and $m_{\text {total }}$ increase as $Q$ and $H$ increase. For instance, the increase in flow rate from 2 to $7 \mathrm{~mL} \mathrm{~min}{ }^{-1}$ allows an increase in $m_{\text {total }}$ of $0.74 \mathrm{mg}$ when working at a bed height of $15 \mathrm{~cm}$. On the contrary, with high flow rates $q_{\text {total }}$ decreased, but it increases with the increase in $H$. In the case of the adsorption capacity, it is inversely proportional to the

Table 5 Operating parameters of the adsorption column with sugarcane bagasse

\begin{tabular}{|c|c|c|c|c|c|c|c|c|c|c|}
\hline $\begin{array}{l}\mathrm{Q} \\
\left(\mathrm{mL} \min ^{-1}\right)\end{array}$ & $\mathrm{H}(\mathrm{cm})$ & $t_{b}(\min )$ & $\begin{array}{l}t_{s} \\
(\min )\end{array}$ & $\begin{array}{l}V \\
(\mathrm{~mL})\end{array}$ & LUB $(\mathrm{cm})$ & $\begin{array}{l}q_{\text {total }} \\
(\mathrm{mg})\end{array}$ & $\begin{array}{l}m_{\text {total }} \\
(\mathrm{mg})\end{array}$ & $\begin{array}{l}q_{\mathrm{e}} \\
\left(\mathrm{mg} \mathrm{g}^{-1}\right)\end{array}$ & $\begin{array}{l}\mathrm{q}_{\mathrm{e}, \mathrm{s}} \\
\left(\mathrm{mg} \mathrm{s}^{-2}\right)\end{array}$ & $\overline{\% R}$ \\
\hline 2 & 15 & 22.8 & 76.0 & 152 & 10.49 & 1.62 & 1.45 & 0.20 & 0.091 & 68 \\
\hline 5 & 15 & 13.0 & 57.2 & 286 & 11.59 & 1.20 & 2.48 & 0.19 & 0.067 & 64 \\
\hline 7 & 15 & 10.8 & 43.0 & 301 & 11.23 & 0.93 & 2.04 & 0.16 & 0.052 & 60 \\
\hline 2 & 25 & 60.8 & 141.8 & 284 & 14.28 & 0.81 & 0.79 & 0.23 & 0.079 & 74 \\
\hline 5 & 25 & 21.1 & 97.8 & 489 & 19.60 & 0.75 & 1.47 & 0.17 & 0.074 & 58 \\
\hline 7 & 25 & 17.3 & 57.3 & 401 & 17.46 & 0.65 & 1.53 & 0.13 & 0.064 & 64 \\
\hline
\end{tabular}



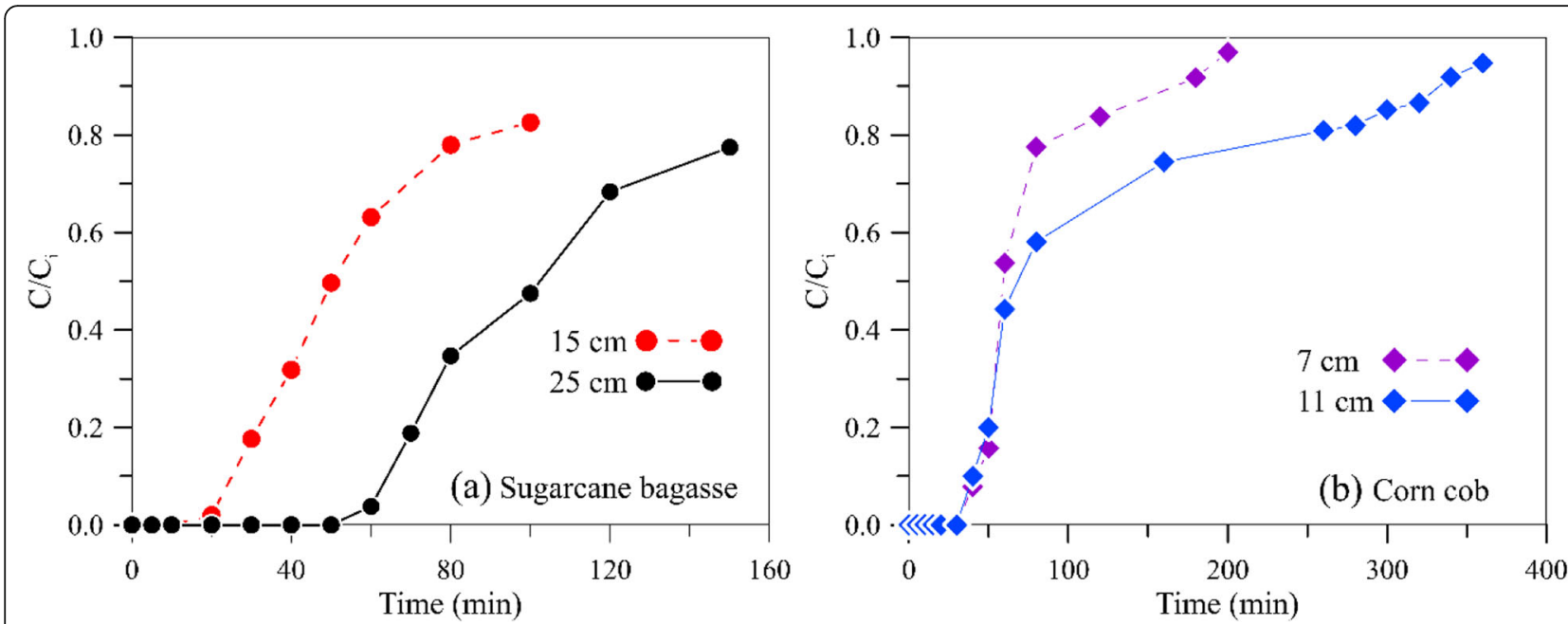

Fig. 4 Influence of bed height on the breakthrough curve of the SMX adsorption with an initial concentration of $5 \mathrm{mg} \mathrm{L}^{-1}$ and $2 \mathrm{~mL} \mathrm{~min}^{-1}$ of flow rate

feed flow rate, but no particular trend was observed with bed height. However, $q_{e}$ and $q_{\text {total }}$ values are higher at a flow rate of $2 \mathrm{~mL} \mathrm{~min}^{-1}$ and $25 \mathrm{~cm}$ of bed height. Similarly, the maximum \% R was $74 \%$, at the same operating conditions. This occurs since there is a greater number of active sites available and a longer contact time between SMX and SB at higher bed heights and lower flow rates.

When the column is packed with $\mathrm{CC}$, the performance parameters have the same behavior as with SB (Table 6). The maximum values of $V$ and $m_{\text {total }}$ are presented at the highest $H$ and $Q$. In contrast, \% $\mathrm{R}$ is very favorable at the lowest flow rate and bed height. Additionally, the maximum $q_{\text {total }}$ and $q_{e}$ were favored at $2 \mathrm{~mL} \mathrm{~min}^{-1}$ and $11 \mathrm{~cm}$ of bed height. The main reason why $q_{e}$ decreases with increasing the flow rate may be due to the reduced contact time between the SMX solution and the pores of adsorbents. In this way, at high flow rates, all adsorbent active sites are not accessible and are not fully occupied for SMX. These results are in agreement with other studies on the removal of antibiotics [31,32]. The $q_{e}$ also decreases with increasing $H$ due to the overlap of active sites with the increase in adsorbent mass or bed height, indicating that not all these sites are accessible by the
SMX molecule. Similarly, channeling effects and poor solution distribution may be other factors in this effect [33]. Similar behavior has been reported by Gupta and Garg [31] in the ciprofloxacin removal using activated carbon, and Saadi et al. [32] in the azithromycin adsorption by modified clinoptilolite.

\section{Comparison of SB and CC}

In order to establish which adsorbent has better properties for the SMX removal, the breakthrough curves obtained under the same operating conditions were compared. Figure 5a shows the curves of SB and CC resulting at 2 and $5 \mathrm{~mL} \mathrm{~min}^{-1}$, with an adsorbent mass of $6 \mathrm{~g}$. The curves with SB are much longer in time than those with $\mathrm{CC}$, and therefore, the area above the breakthrough curves is greater when using SB. This shows that the SMX has a higher affinity for the active sites of $\mathrm{SB}$ rather than CC. For this reason, $\% R$ and $q_{e}$ were higher with $\mathrm{SB}$ in all the tests carried out (Fig. $5 \mathrm{~b}$ ). In certain cases, $q_{e}$ triples when SB is used versus CC; as it is the case of the test at $7 \mathrm{~mL} \mathrm{~min}^{-1}$ and $6 \mathrm{~g}$, in which $q_{e}$ was $0.20 \mathrm{mg} \mathrm{g}^{-1}$ with SB and only $0.067 \mathrm{mg} \mathrm{g}^{-1}$ with CC. The maximum $q_{e}$ for $\mathrm{SB}$ and $\mathrm{CC}$ obtained was 0.24 and $0.15 \mathrm{mg} \mathrm{g}^{-1}$, respectively. Additionally, the adsorption

Table 6 Operating parameters of the adsorption column with the corn cob

\begin{tabular}{|c|c|c|c|c|c|c|c|c|c|c|}
\hline $\begin{array}{l}\mathrm{Q} \\
\left(\mathrm{mL} \min ^{-1}\right)\end{array}$ & $\begin{array}{l}\mathrm{H} \\
(\mathrm{cm})\end{array}$ & $\begin{array}{l}t_{b} \\
(\min )\end{array}$ & $t_{s}(\min )$ & $\begin{array}{l}V \\
(\mathrm{~mL})\end{array}$ & $\begin{array}{l}\text { LUB } \\
(\mathrm{cm})\end{array}$ & $\begin{array}{l}q_{\text {total }} \\
(\mathrm{mg})\end{array}$ & $\begin{array}{l}\mathrm{m}_{\text {total }} \\
(\mathrm{mg})\end{array}$ & $\begin{array}{l}q_{\mathrm{e}} \\
\left(\mathrm{mg} \mathrm{g}^{-1}\right)\end{array}$ & $\begin{array}{l}\mathrm{q}_{\mathrm{e}, \mathrm{s}} \\
\left(\mathrm{mg} \mathrm{s}^{-2}\right)\end{array}$ & $\overline{\% R}$ \\
\hline 2 & 7 & 36.3 & 77.9 & 156 & 3.73 & 0.50 & 0.77 & 0.13 & 0.106 & 65 \\
\hline 5 & 7 & 2.1 & 35.5 & 177 & 6.60 & 0.51 & 0.88 & 0.13 & 0.106 & 58 \\
\hline 7 & 7 & 0.5 & 27.5 & 192 & 6.88 & 0.41 & 0.96 & 0.10 & 0.082 & 43 \\
\hline 2 & 11 & 35.1 & 168.2 & 336 & 8.71 & 0.93 & 1.68 & 0.15 & 0.123 & 56 \\
\hline 5 & 11 & 2.4 & 60.4 & 302 & 10.56 & 0.74 & 1.51 & 0.12 & 0.098 & 49 \\
\hline 7 & 11 & 0.3 & 47.9 & 335 & 10.93 & 0.43 & 1.68 & 0.07 & 0.057 & 26 \\
\hline
\end{tabular}




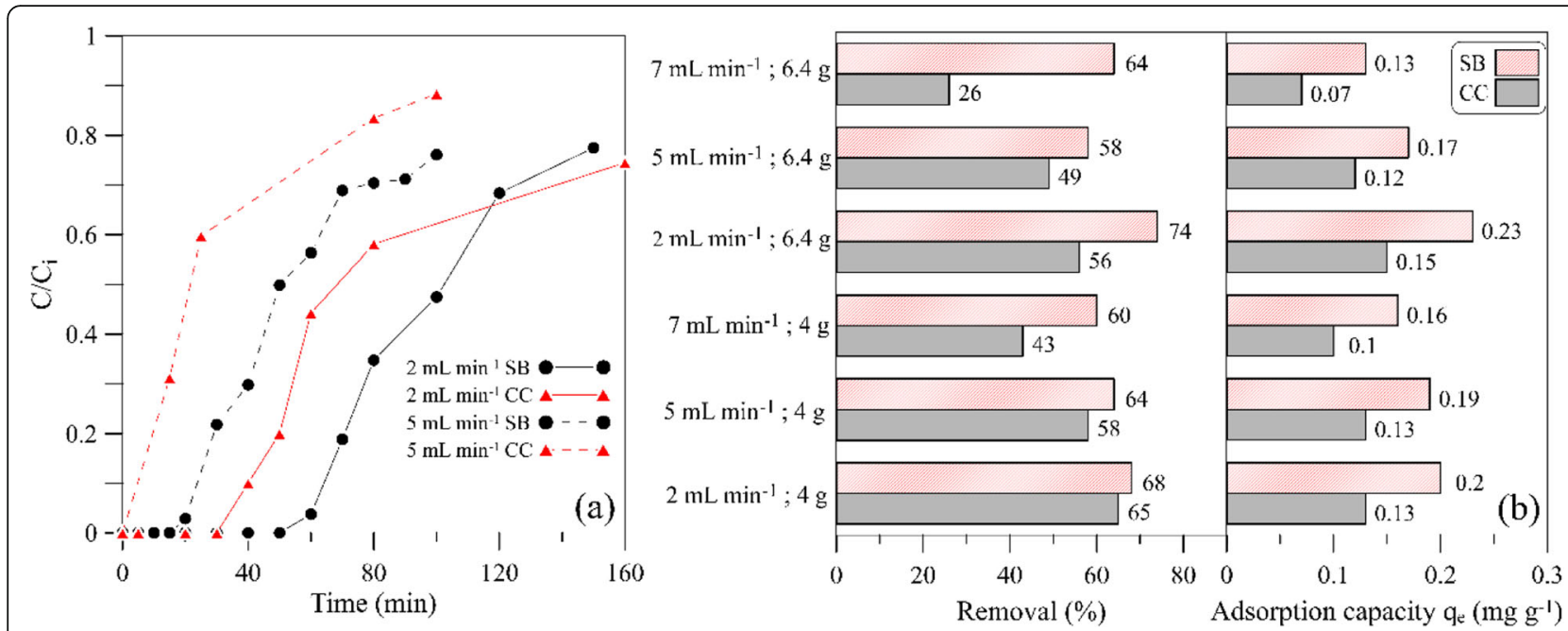

Fig. 5 Breakthrough curves (a) and operating parameters (b) of the SMX adsorption with SB and CC with an initial concentration of 5 mg L ${ }^{-1}$

capacity per surface $\left(q_{e, s}\right)$ was estimated and are illustrated in Tables 5 and 6 . These results indicate that CC has higher adsorption capacity per surface than $\mathrm{CC}$ in almost all adsorption tests. The maximum $q_{e, s}$ for SB and $C C$ was 0.091 , and $0.12 \mathrm{mg} \mathrm{s}^{-2}$, respectively. This fact is mainly attributed to the low specific surface area of CC. Similar results were obtained by Penafiel et al. [17], where SB had higher adsorption capacity per surface than activated carbon; nonetheless the activated carbon had an adsorption capacity 10 times higher than SB to remove ciprofloxacin.

The fact that SB has better adsorption properties against CC can be mainly attributed to its higher specific surface, which means a greater number of active sites available for the SMX adsorption. Also, the chemical properties of SB can promote better adsorption of SMX. SB has a slightly higher amount of acid groups than CC (Table 4), this implies more carboxyl, lactone, and phenolic hydroxy functional groups, resulting in a higher adsorption capacity [26].

Additionally, SMX has two $\mathrm{pK}_{\mathrm{a}}$ values (Table 1), $\mathrm{pK}_{\mathrm{a} 1}=1.7$ corresponds to the protonation of the amino group $\left(-\mathrm{NH}_{2}\right)$, while $\mathrm{pK}_{\mathrm{a} 2}=5.7$ corresponds to the deprotonation of the amide group (-NH-) (Fig. 6a and Table 1). SMX will be predominantly positively charged if $\mathrm{pH}<\mathrm{pK}_{\mathrm{a} 1}\left(\mathrm{SMX}^{+}\right)$, as a neutral species if $\mathrm{pK}_{\mathrm{a} 1}<\mathrm{pH}<$ $\mathrm{pK}_{\mathrm{a} 2}\left(\mathrm{SMX}^{0}\right)$, and negatively charged if $\mathrm{pH}>\mathrm{pK}_{\mathrm{a} 2}$ $\left(\mathrm{SMX}^{-}\right)$[34]. Similarly, according to the $\mathrm{pH}_{\mathrm{PZC}}$ of $\mathrm{SB}$ and $\mathrm{CC}$, at $\mathrm{pH}$ of $6 \mathrm{SB}$ has a neutral global charge on its surface, and CC surface is negatively charged. This condition causes electrostatic repulsions between $\mathrm{SMX}^{-}$and $\mathrm{CC}$ with a decrease in the adsorption of the SMX, and there were no electrostatic interactions between $\mathrm{SMX}^{-}$ and SB.

Furthermore, the formation of hydrogen bonds and hydrophobic interactions have been reported as

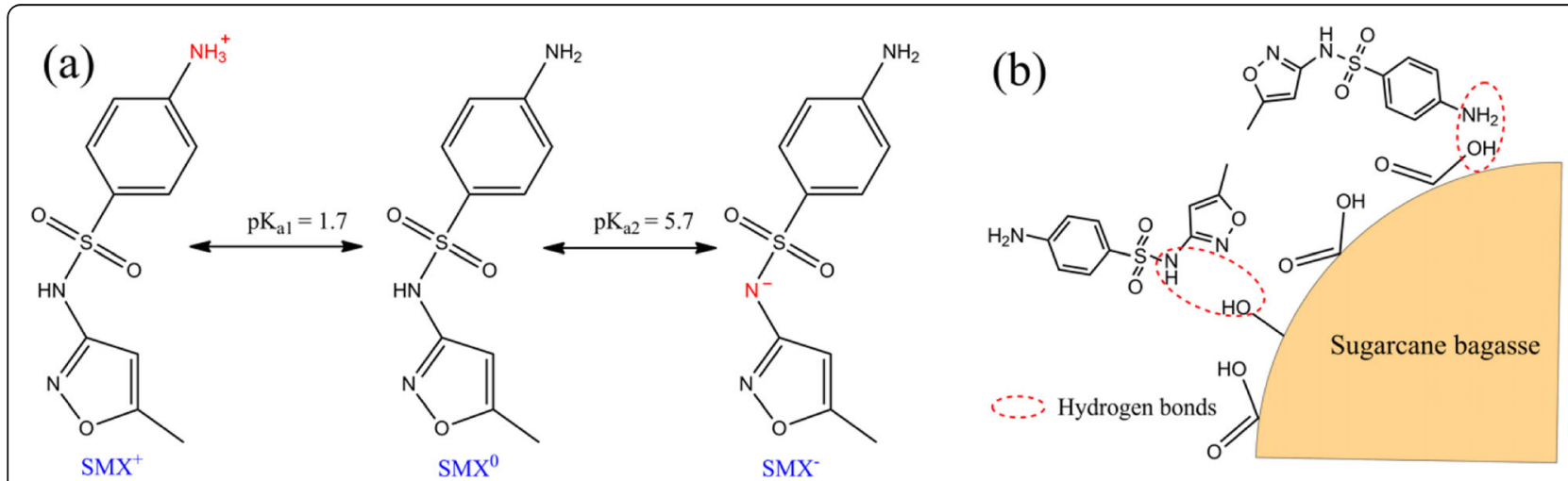

Fig. 6 Protonation and deprotonation of sulfamethoxazole molecule (a), and hydrogen bonding (b) 
predominant mechanisms in the adsorption of SMX using activated carbon, clays, and resins [35]. Most of the time, hydrogen bonds were formed between $-\mathrm{NH}_{2}$ or $\mathrm{SO}_{2} \mathrm{~N}$ - groups of SMX with the carbonyl $(-\mathrm{COOH})$, hydroxyl $(-\mathrm{OH})$, and primary amide $\left(-\mathrm{NH}_{2}\right)$ functional groups of the adsorbent. As the functional groups $-\mathrm{COOH}$ and $-\mathrm{OH}$ are mostly present in $\mathrm{SB}$ and $\mathrm{CC}$, the possibility of hydrogen bonding as a dominant mechanism in SMX adsorption is not ruled out (Fig. 6b). Finally, the adsorption capacity and removal percentage of CC and SB were compared with other biosorbents, which were used to remove antibiotics as detailed in Table 7 . As can be seen, the adsorption properties for SB and CC are in the same range as other biosorbents. SB and CC had adsorption capacities higher than fish waste to remove SMX, but lower than rice husk and cork.

\section{Transport parameters}

The transport process during SMX adsorption into SB was analyzed. This process involves four steps: bulk transport by diffusion and convection, film diffusion, intraparticle diffusion, and adsorptiondesorption reaction (Fig. 7). It is well known that the second and third stages occur slowly, and either could be the rate-limiting step in the adsorption process.

The tortuosity factor for SB was 15.3, which is agreement with the value reported by Pauletto et al. [24]; the high tortuosity is due to the fact that the pore geometry of sugarcane bagasse is more disordered and chaotic compared commercial adsorbents such as activated carbon [24]. The estimated values of $D_{s}, D_{p}$, and $k_{f}$ are presented in Table 8 ; as can be seen, both $D_{s}$ and $D_{p}$ are not affected by changes in operation conditions, and were $3.86 \times 10^{-12}$ and $9.89 \times 10^{-12} \mathrm{~m}^{2} \mathrm{~s}^{-1}$, respectively; which are in the range reported for other agro-waste adsorbents [24], which indicates that the pore and surface diffusion present high resistance in the transport processes. On the other hand, $k_{f}$ increases with the change in flow rate, this is because the thickness of the liquid film decreases as the flow rate increases [23]. Similarly, to $D_{s}$ and $D_{p}, D_{e}$ did not change with $\mathrm{Q}$ and $\mathrm{H}$, and it was $6.68 \times 10^{-12} \mathrm{~m}^{2} \mathrm{~s}^{-1}$. Finally, the ratelimiting step was established with the Biot number (Bi), which measures the relative rate between film diffusion and intraparticle diffusion.

$$
B i=\frac{k_{f} d_{p} C_{i}}{2 D_{e} \rho_{p} q_{e}}
$$

According to Pauletto et al. [24], if $\mathrm{Bi}<0.5$ the film or external diffusion is the rate-limiting step, while if $\mathrm{Bi}>30$, the intraparticle diffusion predominates and controls the adsorption. In this study, Bi numbers for all test are larger than 30, indicating that intraparticle diffusion is the rate controlling step for the SMX adsorption on SB. Additionally, it was observed that $\mathrm{Bi}$ number increases with the flow rate, which means that the film diffusion resistance decreases and the interparticle diffusion is more relevant as the flow rate increases.

Table 7 Comparison of adsorption properties with other biosorbents

\begin{tabular}{|c|c|c|c|c|}
\hline Biosorbent & Antibiotic & $\mathrm{q}_{\mathrm{e} \_\max }\left(\mathrm{mg} \mathrm{g}^{-1}\right)$ & \% Removal & Reference \\
\hline Fish waste & Sulfamethoxazole & 0.002 & 62 & [36] \\
\hline Fish waste & Trimethoprim & 0.046 & 56 & [36] \\
\hline Sugarcane bagasse & Acetaminophen & 0.38 & - & {$[21]$} \\
\hline Sugarcane bagasse & Ciprofloxacin & 9.37 & - & {$[17]$} \\
\hline Sugarcane bagasse & Tetracycline & 0.17 & 98 & {$[20]$} \\
\hline Corn Cob & Ciprofloxacin & 2.23 & 60 & {$[37]$} \\
\hline Corn cob & Sulfamethoxazole & 0.35 & 52 & {$[28]$} \\
\hline Corn Cob & Acetaminophen & 0.42 & - & [21] \\
\hline Rice Husk & Ciprofloxacin & 5.61 & 56 & {$[37]$} \\
\hline Cork Bark & Acetaminophen & 0.99 & - & [38] \\
\hline Agricultural soil & Sulfamethoxazole & 0.35 & - & [16] \\
\hline Cork & Ibuprofen & 0.32 & 98 & [39] \\
\hline Cork & Carbamazepine & 0.37 & 88 & [39] \\
\hline Pine Wood & Diclofenac & 0.33 & 69 & {$[40]$} \\
\hline Sugarcane bagasse & Sulfamethoxazole & 0.23 & 74 & This work \\
\hline Corn cob & Sulfamethoxazole & 0.15 & 65 & This work \\
\hline
\end{tabular}




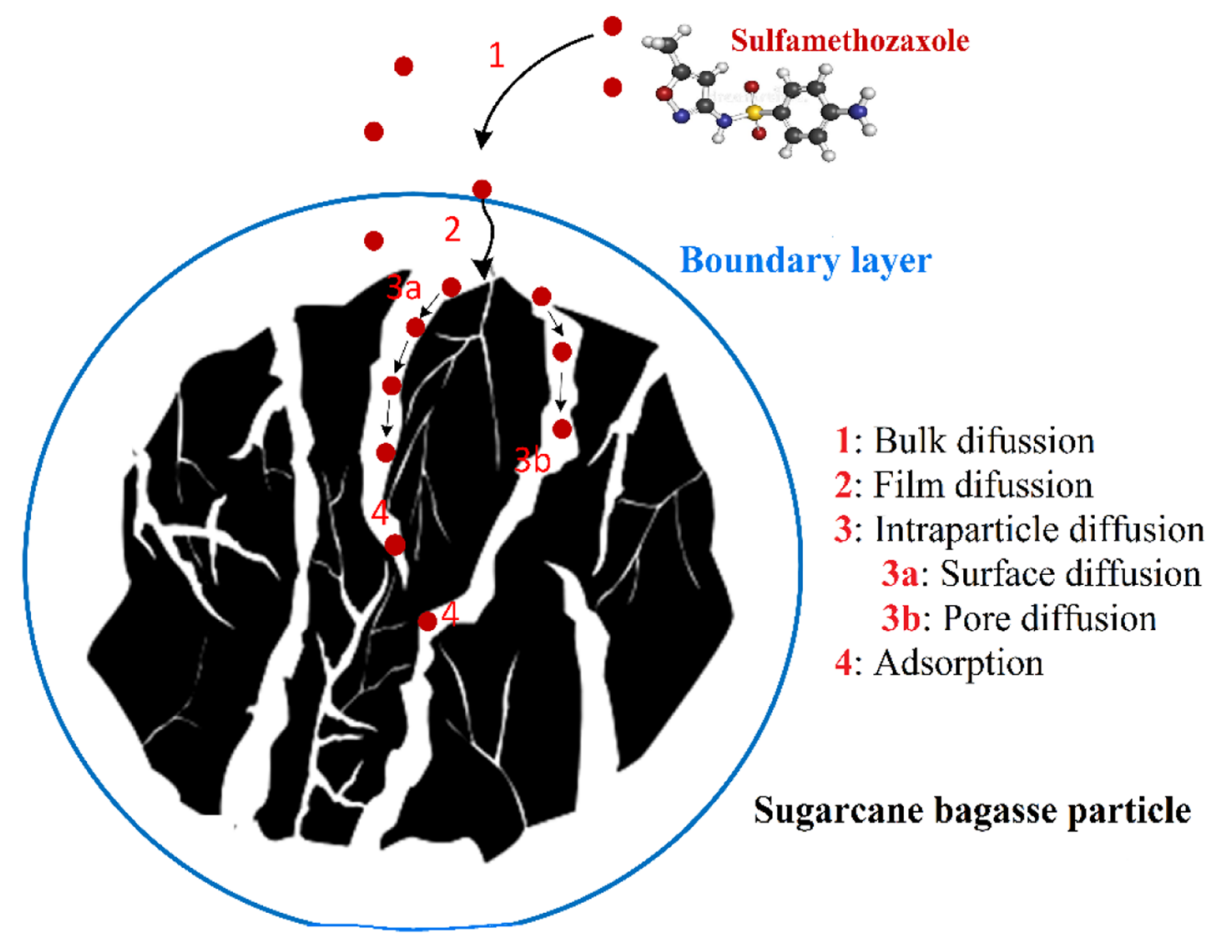

Fig. 7 Transport process during SMX adsorption

It is well known that the surface diffusion is predominant in adsorbents with high content of micropores; however, our previous work has shown that the pore distribution of $\mathrm{SB}$ is more dispersed with predominant larger pores (macropores and mesopores) [17]. Therefore, it can be inferred that the pore diffusion has a higher contribution in the intraparticle diffusion.

\section{Conclusions}

This study characterized and evaluated the adsorption properties of SB and CC to remove SMX from synthetic solutions in a fixed-bed column. The main conclusions about the adsorbents' characterization are that SB had a specific surface area twice that of CC. The point of zero charge was 6.1 for SB and 5.5 for $\mathrm{CC}$; which indicates a slightly acid character. This was corroborated with the Boehm titration results where the functional acid groups were higher than $80 \%$ for both adsorbents; this acid character was mainly due to the presence of carboxylic acid, alcoholic, and phenolic groups. In most fixed-bed experiments, the adsorption capacity of both adsorbents decreased with increasing flow rate and bed height, and the maximum adsorption capacity was 0.24 and $0.15 \mathrm{mg}$ $\mathrm{g}^{-1}$ for $\mathrm{SB}$, and $\mathrm{CC}$, respectively. This indicates that the SMX molecule has a higher affinity for the active sites of SB than for CC. The main factors that explain the better adsorption capacity of SB were a greater surface area, electrostatic attractions, and the formation of hydrogen bonds between SB and SMX. Besides, it was observed that the SMX adsorption was controlled by the intraparticle diffusion, which was more relevant as flow rate increased. Sugarcane has the potential to be used in wastewaters treatment and could be used to extend the study with chemical modifications.

Table 8 Transport parameters at different operating conditions

\begin{tabular}{|c|c|c|c|c|c|c|c|}
\hline $\begin{array}{l}\mathrm{Q} \\
\left(\mathrm{mL} \min ^{-1}\right)\end{array}$ & $\mathrm{H}(\mathrm{cm})$ & $D_{m} \times 10^{-10}\left(m^{2} s^{-1}\right)$ & $k_{f} \times 10^{-6}\left(\mathrm{~m} \mathrm{~s}^{-1}\right)$ & $D_{s} \times 10^{-12}\left(m^{2} s^{-1}\right)$ & $D_{p} \times 10^{-12}\left(m^{2} s^{-1}\right)$ & $D_{e} \times 10^{-12}\left(m^{2} s^{-1}\right)$ & $\mathrm{Bi}$ \\
\hline 2 & $15 / 25$ & 7.18 & 6.61 & 3.86 & 9.89 & 6.68 & 173 \\
\hline 5 & $15 / 25$ & 7.18 & 8.46 & 3.86 & 9.89 & 6.68 & 222 \\
\hline 7 & $15 / 25$ & 7.18 & 9.33 & 3.86 & 9.89 & 6.68 & 244 \\
\hline
\end{tabular}




\section{Acknowledgements}

Not Applicable.

\section{Authors' contributions}

Diego Juela: Investigation, Formal analysis, Writing - original draft, Writing review \& editing. Mayra Vera: Methodology, Writing - original draft, conceptualization. Christian Cruzat: Investigation, Formal analysis. Ximena Alvarez: Investigation. Eulalia Vanegas: Conceptualization, Writing - review \& editing, Supervision, Validation, Resources, Funding acquisition, Project administration. All authors read and approved the final manuscript.

\section{Funding}

This work was supported by SENESCYT and Dirección de Investigación de la Universidad de Cuenca (DIUC) for through the project PIC-18-INE-UC-001 (INEDITA).

\section{Availability of data and materials}

All data generated or analyzed during this study are included in this article or by the corresponding author on reasonable request (eulalia. vanegas@ucuenca.edu.ec).

\section{Declarations}

\section{Competing interests}

The authors declare they have no competing interests.

\section{Received: 27 March 2021 Accepted: 8 August 2021 Published online: 07 September 2021}

\section{References}

1. Masse D, Saady NMC, Gilbert Y. Potential of biological processes to eliminate antibiotics in livestock manure: an overview. Animals. 2014;4:14663.

2. OECD. Pharmaceutical Residues in Freshwater: Hazards and Policy Responses. Paris: The Organisation for Economic Co-operation and Development; 2019.

3. Radke M, Lauwigi C, Heinkele G, Murdter TE, Letzel M. Fate of the antibiotic sulfamethoxazole and its two major human metabolites in a water sediment test. Environ Sci Technol. 2009;43:3135-41.

4. Holtge S, Kreuzig R. Laboratory testing of sulfamethoxazole and its metabolite acetyl-sulfamethoxazole in soil. Clean-Soil Air Water. 2007;35: 104-10.

5. Kone M, Cologgi DL, Lu W, Smith DW, Ulrich AC. Pharmaceuticals in Canadian sewage treatment plant effluents and surface waters: occurrence and environmental risk assessment. Environ Technol Rev. 2013;2:17-27.

6. Sun Q, Li MY, Ma C, Chen XQ, Xie XQ, Yu CP. Seasonal and spatial variations of PPCP occurrence, removal and mass loading in three wastewater treatment plants located in different urbanization areas in Xiamen, China. Environ Pollut. 2016;208:371-81.

7. Paulus GK, Hornstra LM, Alygizakis N, Slobodnik J, Thomaidis N, Medema G. The impact of on-site hospital wastewater treatment on the downstream communal wastewater system in terms of antibiotics and antibiotic resistance genes. Int J Hyg Envir Heal. 2019;222:635-44.

8. Gracia-Lor E, Sancho JV, Serrano R, Hernandez F. Occurrence and removal of pharmaceuticals in wastewater treatment plants at the Spanish Mediterranean area of Valencia. Chemosphere. 2012;87:453-62.

9. Ben YJ, Fu CX, Hu M, Liu L, Wong MH, Zheng CM. Human health risk assessment of antibiotic resistance associated with antibiotic residues in the environment: a review. Environ Res. 2019;169:483-93.

10. Burke V, Richter D, Greskowiak J, Mehrtens A, Schulz L, Massmann G. Occurrence of antibiotics in surface and groundwater of a drinking water catchment area in Germany. Water Environ Res. 2016;88:652-9.

11. Segura PA, Takada H, Correa JA, El Saadi K, Koike T, Onwona-Agyeman S, et al. Global occurrence of anti-infectives in contaminated surface waters: Impact of income inequality between countries. Environ Int. 2015;80:89-97.

12. Ye Z, Weinberg HS, Meyer MT. Occurrence of antibiotics in drinking water. In: 4th International Conference on Pharmaceuticals and Endocrine Disrupting Chemicals in Water. Minneapolis; 2004 13-15.

13. Voloshenko-Rossin A, Gasser G, Cohen K, Gun J, Cumbal-Flores L, ParraMorales W, et al. Emerging pollutants in the Esmeraldas watershed in Ecuador: discharge and attenuation of emerging organic pollutants along the San Pedro-Guayllabamba-Esmeraldas rivers. Environ Sci-Proc Imp. 2015; 17:41-53.

14. Akpe SG, Ahmed I, Puthiaraj P, Yu K, Ahn WS. Microporous organic polymers for efficient removal of sulfamethoxazole from aqueous solutions. Micropor Mesopor Mat. 2020;296:109979.

15. Yu K, Ahmed I, Won Dl, Lee Wl, Ahn WS. Highly efficient adsorptive removal of sulfamethoxazole from aqueous solutions by porphyrinic MOF-525 and MOF-545. Chemosphere. 2020;250:126133.

16. Hu SQ, Zhang Y, Shen GX, Zhang HC, Yuan ZJ, Zhang W. Adsorption/ desorption behavior and mechanisms of sulfadiazine and sulfamethoxazole in agricultural soil systems. Soil Till Res. 2019;186:233-41.

17. Penafiel ME, Matesanz JM, Vanegas E, Bermejo D, Mosteo R, Ormad MP. Comparative adsorption of ciprofloxacin on sugarcane bagasse from Ecuador and on commercial powdered activated carbon. Sci Total Environ. 2021:750:141498.

18. Aseffe JAM, Jaen RL, OlivaRuiz LO, Gonzalez AM, Silva Lora EE. Life cycle analysis of the energy use of the waste (corn cob) of the corn crop ( $Z$. mays) in the province of Los Ríos, Ecuador. Tecnol Quimica. 2019;39:655-72 [in Spanish].

19. Mora JM, García CPP, Najera F. Aprovechamiento del bagazo de caña de azúcar en la fabricación de bloques ecológicos para mampostería liviana [Use of sugarcane bagasse in the manufacture of ecological blocks for light masonry]. Perfiles. 2011;8:16-9 [in Spanish].http://ceaa.espoch.edu.ec:8080/ revista.perfiles/faces/Articulos/Perfiles08Art3.pdf.

20. Ribeiro AVFN, Cosmo PC, Pereira MG, Dalfior BM, Goncalves GS, Licinio MWJ, et al. Use of sugarcane bagasse for adsorption of tetracycline in aqueous medium. Indian J Appl Res. 2011;4:10-4.

21. Juela DM. Comparison of the adsorption capacity of acetaminophen on sugarcane bagasse and corn cob by dynamic simulation. Sustain Environ Res. 2020;30:23.

22. Vera L, Uguna MF, Garcia N, Flores M, Vazquez V, Aloma I. Desarrollo de materiales sorbentes para la eliminación de metales pesados de las aguas residuales mineras [Development of sorbent materials for removing heavy metals from mining wastewater]. Afinidad. 2016;73:135-9 [in Spanish].

23. $\mathrm{Xu} \mathrm{Z}$, Cai JG, Pan BC. Mathematically modeling fixed-bed adsorption in aqueous systems. J Zhejiang Univ-Sc A. 2013:14:155-76.

24. Pauletto PS, Dotto GL, Salau NPG. Diffusion mechanisms and effect of adsorbent geometry on heavy metal adsorption. Chem Eng Res Des. 2020; 157:182-94.

25. Liu H, Zhang J, Jiang L, Kang Y, Cheng C, Guo ZZ, et al. Development of carbon adsorbents with high surface acidic and basic group contents from phosphoric acid activation of xylitol. RSC Adv. 2015;5:81220-8.

26. Yu JM, Kang Y, Yin WJ, Fan JL, Guo ZZ. Removal of antibiotics from aqueous solutions by a carbon adsorbent derived from protein-waste-doped biomass. ACS Omega. 2020;5:19187-93.

27. Ben-Ali S, Jaouali I, Souissi-Najar S, Ouederni A. Characterization and adsorption capacity of raw pomegranate peel biosorbent for copper removal. J Clean Prod. 2017;142:3809-21.

28. Penafiel ME, Matesanz JM, Vanegas E, Bermejo D, Ormad MP. Corncobs as a potentially low-cost biosorbent for sulfamethoxazole removal from aqueous solution. Sep Sci Technol. 2020;55:3060-71.

29. Zhang RY, Zheng XX, Chen BH, Ma JL, Niu XJ, Zhang DQ, et al. Enhanced adsorption of sulfamethoxazole from aqueous solution by Fe-impregnated graphited biochar. J Clean Prod. 2020;256:120662.

30. Altufaily MAM, AL-Mansori NJ, AL-Qaraghulee AFM. Mathematical modeling of fixed-bed columns for the adsorption of methylene blue on to fired clay pot. Int J ChemTech Res. 2019;12:70-80.

31. Gupta A, Garg A. Adsorption and oxidation of ciprofloxacin in a fixed bed column using activated sludge derived activated carbon. J Environ Manage. 2019;250:109474.

32. Saadi Z, Fazaeli R, Vafajoo L, Naser I, Mohammadi G. Promotion of clinoptilolite adsorption for azithromycin antibiotic by Tween 80 and Triton X-100 surface modifiers under batch and fixed-bed processes. Chem Eng Commun. 2021;208:328-48.

33. Marzbali MH, Esmaieli M. Fixed bed adsorption of tetracycline on a mesoporous activated carbon: experimental study and neuro-fuzzy modeling. J Appl Res Technol. 2017;15:454-63.

34. Willach S, Lutze HV, Eckey K, Loppenberg K, Liiling M, Terhalle J, et al. Degradation of sulfamethoxazole using ozone and chlorine dioxide compound-specific stable isotope analysis, transformation product analysis and mechanistic aspects. Water Res. 2017;122:280-9. 
35. Liu XH, Lu SY, Liu Y, Meng W, Zheng BH. Adsorption of sulfamethoxazole (SMZ) and ciprofloxacin (CIP) by humic acid (HA): characteristics and mechanism. RSC Adv. 2017;7:50449-58.

36. Nielsen L, Bandosz TJ. Analysis of sulfamethoxazole and trimethoprim adsorption on sewage sludge and fish waste derived adsorbents. Micropor Mesopor Mat. 2016;220:58-72.

37. Penafiel ME, Vanegas E, Bermejo D, Matesanz JM, Ormad MP. Correction to: Organic residues as adsorbent for the removal of ciprofloxacin from aqueous solution. Hyperfine Interact. 2019;240:108.

38. Villaescusa I, Fiol N, Poch J, Bianchi A, Bazzicalupi C. Mechanism of paracetamol removal by vegetable wastes: the contribution of pi-pi interactions, hydrogen bonding and hydrophobic effect. Desalination. 2011; 270:135-42.

39. Dordio AV, Goncalves P, Texeira D, Candeias AJ, Castanheiro JE, Pinto AP, et al. Pharmaceuticals sorption behaviour in granulated cork for the selection of a support matrix for a constructed wetlands system. Int J Environ An Ch. 2011;91:615-31.

40. Lonappan L, Rouissi T, Brar SK, Verma M, Surampalli RY. An insight into the adsorption of diclofenac on different biochars: mechanisms, surface chemistry, and thermodynamics. Bioresour Technol. 2018;249:386-94.

\section{Publisher's Note}

Springer Nature remains neutral with regard to jurisdictional claims in published maps and institutional affiliations.

Ready to submit your research? Choose BMC and benefit from:

- fast, convenient online submission

- thorough peer review by experienced researchers in your field

- rapid publication on acceptance

- support for research data, including large and complex data types

- gold Open Access which fosters wider collaboration and increased citations

- maximum visibility for your research: over $100 \mathrm{M}$ website views per year

At $\mathrm{BMC}$, research is always in progress.

Learn more biomedcentral.com/submissions 